\title{
A kinetic analysis of leaf uptake of COS and its relation to transpiration, photosynthesis and carbon isotope fractionation
}

\author{
U. Seibt ${ }^{1}$, J. Kesselmeier ${ }^{2}$, L. Sandoval-Soto ${ }^{2, *}$, U. Kuhn ${ }^{2, * *}$, and J. A. Berry ${ }^{3}$ \\ ${ }^{1}$ Université Pierre et Marie Curie Paris 6, UMR BioEmco, Campus ParisAgroTech, 78850 Thiverval-Grignon, France \\ ${ }^{2}$ Max Planck Institute for Chemistry, Biogeochemistry Dept., Joh.-J.-Becher-Weg 27, 55128 Mainz, Germany \\ ${ }^{3}$ Carnegie Institution for Science, Department of Global Ecology, 260 Panama St., Stanford, CA 94305-1297, USA \\ *now at: Fachhochschule Nordwestschweiz, Hochschule für Life Sciences, Institut für Ecopreneurship, Gründenstraße 40, \\ 4132 Muttenz, Switzerland \\ **now at: Agroscope Reckenholz-Tänikon Research Station ART, Reckenholzstraße 191, 8046 Zürich, Switzerland
}

Received: 12 August 2009 - Published in Biogeosciences Discuss.: 25 September 2009

Revised: 24 December 2009 - Accepted: 12 January 2010 - Published: 28 January 2010

\begin{abstract}
Carbonyl sulfide (COS) is an atmospheric trace gas that holds great promise for studies of terrestrial carbon and water exchange. In leaves, COS follows the same pathway as $\mathrm{CO}_{2}$ during photosynthesis. Both gases are taken up in enzyme reactions, making $\mathrm{COS}$ and $\mathrm{CO}_{2}$ uptake closely coupled at the leaf scale. The biological background of leaf COS uptake is a hydrolysis reaction catalyzed by the enzyme carbonic anhydrase. Based on this, we derive and test a simple kinetic model of leaf COS uptake, and relate $\mathrm{COS}$ to $\mathrm{CO}_{2}$ and water fluxes at the leaf scale. The equation was found to predict realistic leaf COS fluxes compared to observations from field and laboratory chambers. We confirm that COS uptake at the leaf level is directly linked to stomatal conductance. As a consequence, the ratio of normalized uptake rates (uptake rates divided by ambient mole fraction) for leaf COS and $\mathrm{CO}_{2}$ fluxes can provide an estimate of $C_{i} / C_{a}$, the ratio of intercellular to atmospheric $\mathrm{CO}_{2}$, an important plant gas exchange parameter that cannot be measured directly. The majority of published normalized $\mathrm{COS}$ to $\mathrm{CO}_{2}$ uptake ratios for leaf studies on a variety of species fall in the range of 1.5 to 4 , corresponding to $C_{i} / C_{a}$ ratios of 0.5 to 0.8 . In addition, we utilize the coupling of $C_{i} / C_{a}$ and photosynthetic ${ }^{13} \mathrm{C}$ discrimination to derive an estimate of $2.8 \pm 0.3$ for the global mean normalized uptake ratio. This corresponds to a global vegetation sink of COS in the order of $900 \pm 100 \mathrm{Gg} \mathrm{S} \mathrm{yr}^{-1}$. $\mathrm{COS}$ can now be implemented in the same model framework as $\mathrm{CO}_{2}$ and water vapour. Atmospheric $\mathrm{COS}$ measurements can then provide independent constraints on $\mathrm{CO}_{2}$ and water cycles at ecosystem, regional and global scales.
\end{abstract}

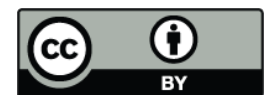

Correspondence to: U. Seibt (ulli@atmos.ucla.edu)

\section{Introduction}

Carbonyl sulfide (COS) is a source of stratospheric sulfate aerosols and plays an important role in stratospheric ozone chemistry (Crutzen, 1976; Andreae and Crutzen, 1997). Globally, the main source of COS is the ocean, and uptake by leaves and soil are the main sinks (Kettle et al., 2002; Kesselmeier et al., 1999; van Diest et al., 2008). The seasonality of COS in the northern extratropical atmosphere is dominated by COS uptake by terrestrial vegetation (Montzka et al., 2007; Suntharalingam et al., 2008). This is because COS is taken up in enzyme reactions in leaves, similar to $\mathrm{CO}_{2}$. But in contrast to $\mathrm{CO}_{2}$, there is no concurrent $\mathrm{COS}$ release from terrestrial ecosystems. Monitoring atmospheric COS concentration can thus provide valuable information on terrestrial gross carbon fluxes that cannot be obtained by measuring $\mathrm{CO}_{2}$ alone.

Based on the close coupling of leaf $\operatorname{COS}$ and $\mathrm{CO}_{2}$ uptake, the global COS sink by vegetation has been often derived from estimates of $\mathrm{CO}_{2}$ fluxes (Chin and Davis, 1993; Kesselmeier et al., 1993; Andreae and Crutzen, 1997; Watts, 2000; Kettle et al., 2002; Sandoval-Soto et al., 2005). Recently, it has been proposed to invert this approach, with the aim to obtain estimates of global terrestrial gross $\mathrm{CO}_{2}$ uptake from atmospheric COS measurements (Montzka et al., 2007; Campbell et al., 2008; Suntharalingam et al., 2008). COS fluxes have been converted into $\mathrm{CO}_{2}$ fluxes, or vice versa, using the ratio of $\mathrm{COS}$ to $\mathrm{CO}_{2}$ deposition velocities (uptake rates divided by ambient concentration) observed during chamber experiments (Sandoval-Soto et al., 2005). The ratio of deposition velocities is identical to the normalized uptake ratio (see Sect. 5). Most ratios are $>1$, with typical values between 2 and 3 . This has been interpreted as a preferential

Published by Copernicus Publications on behalf of the European Geosciences Union. 
reaction for $\mathrm{COS}$ over $\mathrm{CO}_{2}$ by carbonic anhydrase (CA), the enzyme responsible for the irreversible reaction of COS in leaves (Kesselmeier and Merk, 1993; Protoschill-Krebs et al., 1996).

Here, we introduce a process-oriented description of COS uptake at the leaf level, analogous to that for leaf $\mathrm{CO}_{2}$ and water fluxes. To test the equation, we compare predicted COS uptake to data obtained in field and laboratory chambers (Kuhn et al., 1999; Sandoval-Soto et al., 2005). The new description directly relates COS uptake at the leaf level to stomatal conductance. As a consequence, the normalized uptake ratio for leaf $\mathrm{COS}$ and $\mathrm{CO}_{2}$ fluxes can provide an estimate of $C_{i} / C_{a}$, the ratio of intercellular to atmospheric $\mathrm{CO}_{2}$, an important plant gas exchange parameter that cannot be measured directly.

\section{Expressing leaf exchange of $\mathrm{COS}$ in analogy to $\mathrm{CO}_{2}$ and water vapour}

Based on Fick's law of diffusion, leaf fluxes can be described as the product of conductance and concentration gradient (Penman and Schofield, 1951; Cowan, 1977). For example, the transpiration flux, $F_{w}\left(\mathrm{mmolm}^{-2} \mathrm{~s}^{-1}\right)$, is calculated from:

$F_{w}=g_{w}\left(w_{i}-w_{a}\right)$

where $w_{a}$ and $w_{i}\left(\mathrm{mmolmol}^{-1}\right)$ are the vapour mole fractions of ambient air and intercellular spaces, respectively, and $g_{w}\left(\mathrm{molm}^{-2} \mathrm{~s}^{-1}\right)$ is the leaf conductance to water vapour diffusion. For ecosystem studies, $g_{w}$ is composed of leaf boundary layer $\left(g_{b w}\right)$ and stomatal conductance $\left(g_{s w}\right): g_{w}=$ $\left(1 / g_{s w}+1 / g_{b w}\right)^{-1}$. In chamber studies, fans often provide enough ventilation to render the boundary layer component negligible, and $g_{w} \approx g_{s w}$. Leaf conductance is usually obtained from measured values of transpiration $\left(F_{w}\right)$, vapour mole fraction at measured air temperature and relative humidity $\left(w_{a}\right)$, and assuming saturated air at measured leaf temperature $\left(w_{i}\right)$.

Similarly, photosynthetic $\mathrm{CO}_{2}$ uptake, $F_{c}\left(\mu \mathrm{mol} \mathrm{m}{ }^{-2} \mathrm{~s}^{-1}\right)$, can be calculated from:

$F_{c}=g_{s c}\left(C_{a, c}-C_{i, c}\right)$

where $C_{a, c}$ and $C_{i, c}\left(\mu \mathrm{molmol}^{-1}\right)$ are the mole fractions of $\mathrm{CO}_{2}$ in ambient air and intercellular spaces, respectively, and $g_{s c}\left(\mathrm{molm}^{-2} \mathrm{~s}^{-1}\right)$ is the stomatal conductance to $\mathrm{CO}_{2}$ (again, for well ventilated chamber measurements). In contrast to water vapour, it is impossible to directly estimate $C_{i, c}$, and hence to obtain $g_{s c}$ from measurements of $F_{c}$ and $C_{a, c}$. Thus, $g_{s c}$ is usually derived from $g_{s w}$ based on the known relationship between $\mathrm{CO}_{2}$ and water vapour conductances: $g_{s c}=g_{s w} / R_{w-c}$, where $R_{w-c} \approx 1.6$ (Lide, 2008) is the ratio of water vapour and $\mathrm{CO}_{2}$ diffusivities.
In analogy to the above, the equation for leaf COS uptake, $F_{\mathrm{COS}}\left(\mathrm{pmolm}^{-2} \mathrm{~s}^{-1}\right)$, can be written as:

$F_{\mathrm{COS}}=g_{t} \operatorname{COS}\left(C_{a \mathrm{COS}}-C_{m \mathrm{COS}}\right)$

where $C_{a \mathrm{COS}}$ and $C_{m \mathrm{COS}}\left(\mathrm{pmolmol}^{-1}\right)$ are the mole fractions of COS in ambient air and at the reaction sites with the enzyme carbonic anhydrase (CA), respectively. The above combines two diffusion steps: from $C_{a \mathrm{COS}}$ to $C_{i} \mathrm{COS}$ in the intercellular spaces (equivalent to $C_{i, c}$ in Eq. 2), and from $C_{i \mathrm{COS}}$ to $C_{m} \mathrm{COS}$ within the mesophyll cells. In other words, we consider a different diffusion endpoint for COS $\left(C_{a}\right.$ to $\left.C_{m}\right)$ than for $\mathrm{CO}_{2}\left(C_{a}\right.$ to $\left.C_{i}\right)$. Accordingly, the leaf conductance to $\operatorname{COS}\left(g_{t} \mathrm{COS}\right)$ includes both stomatal conductance $\left(g_{s \mathrm{COS}}\right)$ and internal conductance $\left(g_{i \mathrm{COS}}: F_{\mathrm{COS}}=\right.$ $\left.g_{i \mathrm{COS}}\left(C_{i \operatorname{COS}}-C_{m \mathrm{COS}}\right)\right)$ to account for the transfer of COS into the mesophyll cells (and the biochemical reaction rates): $g_{t} \operatorname{COS}=\left(1 / g_{s} \operatorname{COS}+1 / g_{i} \mathrm{COS}\right)^{-1}$. The spatial distribution of $\mathrm{CA}$ in leaf mesophyll cells is not known. We expect a location "upstream" of Rubisco, the enzyme responsible for the reaction with $\mathrm{CO}_{2}$ in the chloroplasts. This is because $\mathrm{CA}$ enhances the solution of $\mathrm{CO}_{2}$ and thus its supply to Rubisco. Hence, we hypothesize that CA is located directly adjacent to the intercellular spaces, so that $g_{i} \mathrm{COS}$ should be much larger than $g_{s \operatorname{COS}}$.

Carbonic anhydrase is a very efficient catalyst for the reaction $\mathrm{COS}+\mathrm{H}_{2} \mathrm{O} \rightarrow \mathrm{H}_{2} \mathrm{~S}+\mathrm{CO}_{2}$ (Protoschill-Krebs et al., 1996; Notni et al., 2007). COS release has not been observed even at low ambient COS (Sandoval-Soto et al., 2005). Thus, we assume that $C_{m} \operatorname{COS} \ll C_{a} \mathrm{COS}$, so that Eq. (3) can be written to a good approximation as:

$F_{\mathrm{COS}}=g_{t} \mathrm{COS} C_{a \mathrm{COS}}$

The value of $g_{i} \mathrm{COS}$ is not known, but we can obtain a reasonable approximation for $g_{t} \mathrm{COS}$ by assuming a constant internal conductance in $g_{t} \mathrm{COS}=\left(1 / g_{s \operatorname{COS}}+1 / g_{i \mathrm{COS}}\right)^{-1}$. Alternatively, for a fixed stomatal conductance or mean values such as large scale estimates, we can also use a constant ratio of stomatal to internal conductance in $g_{t} \operatorname{COS}=$ $g_{s \operatorname{COS}}\left(1+g_{s \operatorname{COS}} / g_{i \mathrm{COS}}\right)^{-1}$.

Similar to $\mathrm{CO}_{2}$ fluxes, $\mathrm{COS}$ fluxes can now be derived from $C_{a \mathrm{COS}}$ and $g_{s w}$ based on the relationship between COS and water vapour conductances: $g_{s} \operatorname{COS}=g_{s w} / R_{w-\operatorname{COS}}$. The ratio $R_{w-C O S}$ has not been determined experimentally yet. In the following, we provide theoretical and empirically derived estimates of $R_{w-\text { COS }}$.

\section{Ratios of diffusivities of $\mathrm{COS}, \mathrm{CO}_{2}$ and water vapour}

The relationships between stomatal conductances for two different gases correspond to their diffusivity ratios: $\quad R_{w-c}=D_{a, w} / D_{a, c}, \quad R_{w-\operatorname{COS}}=D_{a, w} / D_{a \mathrm{COS}}$, and $R_{c-\mathrm{COS}}=D_{a, c} / D_{a \mathrm{COS}}$, where $D_{a, w}, D_{a, c}$, and $D_{a \mathrm{COS}}$ are the diffusion coefficients of water vapour, $\mathrm{CO}_{2}$ and $\mathrm{COS}$ in air. 
Table 1. Theoretical values of diffusivities $D_{a, g}\left(\mathrm{~cm}^{2} \mathrm{~s}^{-1}\right)$ of water vapour, $\mathrm{CO}_{2}$ and COS in air (parameters taken from Bird et al., 2007). Empirical estimates of $D_{a, w}$ and $D_{a, c}$ from Massman (1998). All estimates were derived for a temperature of 23C, the average air temperature during the chamber experiments. For plants at typical field conditions, the effect of temperature on the ratios of diffusivities is probably small.

\begin{tabular}{ccccccccc}
\hline gas & $\mathrm{M}$ & $\sigma$ & $\Omega_{a, g}$ & $D_{a, g}$ & $\begin{array}{c}R_{w-\mathrm{CO}_{2}} \\
R_{w-\mathrm{COS}}\end{array}$ & $R_{c-\mathrm{COS}}$ & $\begin{array}{c}D_{a, g} \\
\text { emp. }\end{array}$ & $\begin{array}{c}R_{w-\mathrm{CO}_{2}} \\
\text { emp. }\end{array}$ \\
\hline air & 28.96 & 3.62 & & & & & & \\
$\mathrm{H}_{2} \mathrm{O}$ & 18.01 & 2.60 & 1.18 & 0.248 & & & 0.252 & \\
$\mathrm{CO}_{2}$ & 44.01 & 4.00 & 1.04 & 0.150 & 1.66 & & 0.160 & 1.58 \\
$\mathrm{COS}^{60.08}$ & 4.13 & 1.15 & 0.124 & 2.01 & 1.21 & & \\
\hline
\end{tabular}

The diffusion coefficient $D_{a, g}\left(\mathrm{~cm}^{2} \mathrm{~s}^{-1}\right)$ of a gas (subscript $g$ ) in ambient air (subscript $a$ ) can be calculated from Chapman-Enskog theory (Bird et al., 2007):

$D_{a, g}=\frac{3}{16} \sqrt{\frac{2(\mathrm{RT})^{3}}{\pi}\left(\frac{1}{M_{a}}+\frac{1}{M_{g}}\right)} \frac{1}{N_{A} p \sigma_{a, g}^{2} \Omega_{a, g}}$

where $R\left(8.31 \mathrm{JK}^{-1} \mathrm{~mol}^{-1}\right)$ is the gas constant, $T(\mathrm{~K})$ is temperature, $M\left(\mathrm{gmol}^{-1}\right)$ is the molar mass of the gas, $N_{A}$ $\left(6.02210^{23} \mathrm{~mol}^{-1}\right)$ is the Avogadro constant, $p$ (atm) is ambient pressure, $\sigma_{a, g}=\left(\sigma_{a}+\sigma_{g}\right) / 2(\AA)$ is the collision diameter of the molecules, and $\Omega_{a, g}$ is the dimensionless collision integral for diffusion. This approach was chosen because it provides molecular parameters for all three gases (Bird et al., 2007).

Theoretical values of diffusion coefficients for water vapour, $\mathrm{CO}_{2}$ and $\mathrm{COS}$ in air are summarized in Table 1 . The theoretical diffusivity ratio for $\mathrm{CO}_{2}$ and water is 1.66 , somewhat higher than the empirical estimate of 1.58 (Massman, 1998). Based on the difference between theoretical and empirical estimate, as well as the analysis of uncertainties presented in Massman (1998), theoretically predicted diffusivity ratios are probably within $10 \%$ of the empirical values. Thus, the resulting diffusivity ratios for $\operatorname{COS}$ are $R_{w-\operatorname{COS}}=2.0 \pm 0.2$ with respect to water vapour, and $R_{c-\operatorname{COS}}=1.2 \pm 0.1$ with respect to $\mathrm{CO}_{2}$.

\section{Testing the leaf COS equation with chamber observations}

To evaluate the relationships developed in the previous section, we calculate leaf COS uptake using Eq. (4) with the theoretical estimate of $R_{w-\mathrm{COS}}$, and compare the predicted to observed COS fluxes. We use concurrent data on transpiration, $\mathrm{COS}$ and $\mathrm{CO}_{2}$ fluxes from leaf-scale chamber measurements (Kuhn et al., 1999; Sandoval-Soto et al., 2005). Briefly, experiments were carried out with an automated system consisting of two dynamic (flow-through) chambers, one with enclosed tree branch, and an empty reference chamber. COS mole fractions were quantified by consecutive sampling in both chambers, and COS uptake determined from their differences (flux $=\Delta$ conc . flowrate/leaf area). Transpiration and net $\mathrm{CO}_{2}$ fluxes were determined similarly from differential measurements of sample vs reference chamber air. We then obtained $g_{s w}$ values from transpiration rates (Eq. 1). In this context, we note that the appropriate values for use in Eqs. (1), (2) and (4) are $w_{a}, C_{a, c}$ and $C_{a} \mathrm{COS}$ in the air surrounding the observed leaves or plants, i.e. in the sample chamber. Often, they first need to be calculated from reference chamber values and flux rates.

One data set was obtained on branches of Fagus sylvatica (European beech) in laboratory chambers (Sandoval-Soto et al., 2005). COS mole fractions were quantified using an automated setup (von Hobe et al., 2000) with an analytical precision of about $8 \mathrm{pmol} \mathrm{mol}^{-1}$, plus any uncertainties in the chamber system (Sandoval-Soto et al., 2005). The average COS mole fractions in the reference and sample chamber were $450 \mathrm{ppt}$ and $340 \mathrm{ppt}$, respectively. Rates of leaf COS uptake were predicted from Eq. (4) using $g_{s w}$ and $C_{a \mathrm{COS}}$ data, and based on $R_{w-\mathrm{COS}}=2$. The predicted fluxes are in good agreement with the observed COS uptake rates over three days of measurements (Fig. 1). As the enzyme reaction of CA with COS is light independent (Protoschill-Krebs et al., 1996), COS uptake can continue in the dark as long as stomata remain open. However, the uncertainties in observed COS fluxes were often larger than the fluxes in the dark (i.e. no significant differences between reference and sample mole fractions).

The second data set was obtained on branches of Quercus agrifolia (Coast Live oak) in field chambers (Kuhn et al., 1999). COS mole fractions were quantified using cryogenic trapping and a gas chromatograph system, with an overall precision of about $25 \mathrm{pmol} \mathrm{mol}^{-1}$ (Kuhn et al., 1999). The predicted COS fluxes are reasonable compared to the measured COS uptake, and mostly within the limits of uncertainties of the measurements (Fig. 2). We only show the results for times where the observed COS fluxes were larger than their uncertainties.

Using Eqs. (1) and (4), and observed chamber mole fractions and flux rates, we also obtained first empirical estimates of $R_{w-\mathrm{COS}}$, the ratio of conductances of COS and water vapour. We assumed a constant $g_{i} \mathrm{COS}$ of $0.2 \mathrm{molm}^{-2} \mathrm{~s}^{-1}$, 


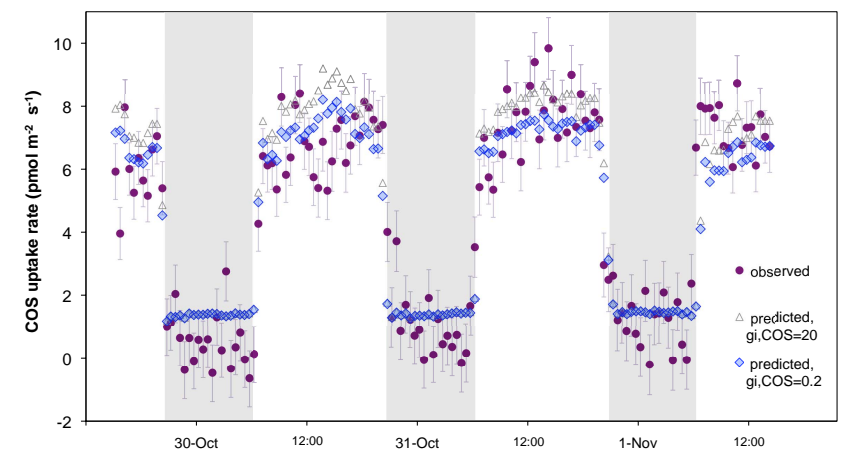

Fig. 1. Leaf COS uptake predicted from transpiration data (Eq. (4), assuming $R_{w-\mathrm{COS}}=2$ and constant internal conductance, $g_{i \mathrm{COS}}=0.2$ ), and observed uptake rates from measurements on $\mathrm{Fa}$ gus sylvatica in laboratory chambers (original data from SandovalSoto et al., 2005). For comparison, we also show predicted rates where internal conductance is assumed to be a negligible limitation to $\mathrm{COS}$ diffusion $\left(g_{i \mathrm{COS}}=20\right)$. Shaded areas indicate measurements in the dark.

relating it to the mean $g_{s} \operatorname{COS}$ for day-time measurements by a factor of ten $\left(g_{s \mathrm{COS}} / g_{i \mathrm{COS}} \approx 0.1\right)$. As a test, we also used $g_{i \mathrm{COS}}$ of $20 \mathrm{molm}^{-2} \mathrm{~s}^{-1}\left(g_{s \mathrm{COS}} / g_{i \mathrm{COS}} \approx 0.001\right)$, i.e. effectively neglecting the internal part of the diffusion pathway. For the re-analysed laboratory data on Fagus sylvatica, the mean ratio was $R_{w-\mathrm{COS}}=2.0 \pm 0.3$ (or 2.2 for $g_{i \mathrm{COS}}=20$ ). For the re-analysed field data on Quercus agrifolia, the mean ratio was $R_{w-\mathrm{COS}}=2.2 \pm 0.8$ (or 2.4 for $g_{i \mathrm{COS}}=20$ ). Both values are close to the theoretical estimate of 2 , but the uncertainties are still large due to the high uncertainties in the measurements of water vapour and particularly COS fluxes.

\section{The normalized uptake ratio of $\mathrm{COS}$ to $\mathrm{CO}_{2}$ as a proxy for $C_{i} / C_{a}$}

COS fluxes can be directly compared to those of $\mathrm{CO}_{2}$ by expressing them as uptake rates normalized by the ambient mole fraction of each gas, $v_{\mathrm{COS}}$ and $v_{\mathrm{CO}_{2}}\left(\mathrm{molm}^{-2} \mathrm{~s}^{-1}\right)$. The normalized uptake ratio $\left(v_{\mathrm{COS}} / v_{\mathrm{CO}_{2}}\right)$ is identical to the ratio of deposition velocities, but instead of using ambient concentrations as in deposition velocities (e.g. (Sandoval-Soto et al., 2005)), normalized uptake rates are defined relative to ambient mole fractions:

$v_{\mathrm{CO}_{2}}=F_{c} / C_{a, c}$

$v_{\mathrm{COS}}=F_{\mathrm{COS}} / C_{a \mathrm{COS}}$

The ratio $v_{\mathrm{COS}} / v_{\mathrm{CO}_{2}}$ was also used in a recent analysis of atmospheric COS data (Campbell et al., 2008) to calculate global COS uptake by vegetation from modelled leaf $\mathrm{CO}_{2}$ fluxes: $F_{\mathrm{COS}}=F_{c}\left(C_{a \mathrm{COS}} / C_{a, c}\right)\left(v_{\mathrm{COS}} / v_{\mathrm{CO}_{2}}\right)$, where $F_{c}$ corresponds to gross primary production (GPP, see Eq. (1) in Campbell et al., 2008).

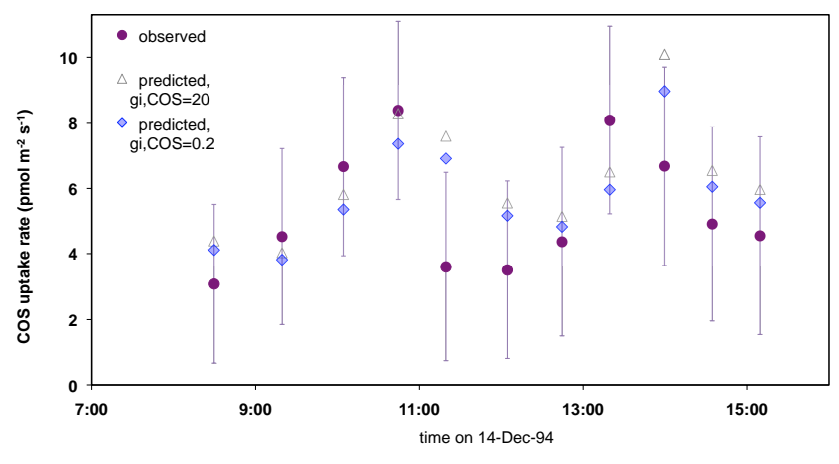

Fig. 2. Leaf COS uptake predicted from transpiration data (Eq. (4), assuming $R_{w-\mathrm{COS}}=2$ and constant internal conductance, $g_{i \mathrm{COS}}=0.2$ ), and observed COS uptake from measurements on Quercus agrifolia in field chambers (original data from Kuhn et al., 1999). For comparison, we also show predicted rates where internal conductance is assumed to be a negligible limitation to COS diffusion $\left(g_{i \mathrm{COS}}=20\right)$.

Using Eqs. (2) and (4), we can rewrite the above definitions as:

$v_{\mathrm{CO}_{2}}=F_{c} / C_{a, c}=g_{s c}\left(1-C_{i, c} / C_{a, c}\right)$

$v_{\mathrm{COS}}=F_{\mathrm{COS}} / C_{a \mathrm{COS}}=g_{\mathrm{COS}}$

Thus, the normalized uptake ratio of $\mathrm{COS}$ to $\mathrm{CO}_{2}$, $v_{\mathrm{COS}} / v_{\mathrm{CO}_{2}}$, can be written as:

$$
\begin{aligned}
v_{\mathrm{COS}} / v_{\mathrm{CO}_{2}} & =\frac{g_{\mathrm{COS}}}{g_{s c}} \frac{1}{1-C_{i} / C_{a}} \\
& =\frac{1}{R_{c-\operatorname{COS}}\left(1+g_{s \operatorname{COS}} / g_{i \operatorname{COS}}\right)\left(1-C_{i} / C_{a}\right)}
\end{aligned}
$$

using $g_{\mathrm{COS}}=\left(1 / g_{s} \mathrm{COS}+1 / g_{i \mathrm{COS}}\right)^{-1}$, and $R_{c-\mathrm{COS}}=$ $g_{s c} / g_{s \operatorname{COS}}$ for the ratio of stomatal conductances. We write $C_{i} / C_{a}$ (instead of $C_{i, c} / C_{a, c}$ ) from hereon for simplicity. The $C_{i} / C_{a}$ ratio is an important plant parameter that cannot be measured directly. It is an expression for the balance between the $\mathrm{CO}_{2}$ supply (limited by stomatal conductance) and demand (limited by light and the efficiency of enzyme reactions). Based on Eq. (8) and the theoretical estimate of the stomatal conductance ratio $\left(R_{c-\mathrm{COS}}=1.2 \pm 0.1\right)$, it should be possible to determine $C_{i} / C_{a}$ from observed fluxes and mole fractions of $\mathrm{COS}$ and $\mathrm{CO}_{2}$ :

$$
\frac{C_{i}}{C_{a}}=1-\frac{1}{R_{c-\mathrm{COS}}\left(1+g_{s} \mathrm{COS} / g_{i \mathrm{COS}}\right) v_{\mathrm{COS}} / v_{\mathrm{CO}_{2}}}
$$

For the estimate of internal COS conductance $\left(g_{s \mathrm{COS}} / g_{i \mathrm{COS}}=0.1\right)$ that is consistent with the $\mathrm{CO}_{2}$ and water data from the laboratory experiments, Eq. (9) can be simplified to: $C_{i} / C_{a} \approx 1-0.75\left(v_{\mathrm{COS}} / v_{\mathrm{CO}_{2}}\right)^{-1}$.

The relationship between $v_{\mathrm{COS}} / v_{\mathrm{CO}_{2}}$ and $C_{i} / C_{a}$ ratios is illustrated in Fig. 3. Values of $v_{\mathrm{COS}} / v_{\mathrm{CO}_{2}}$ between 2 and 


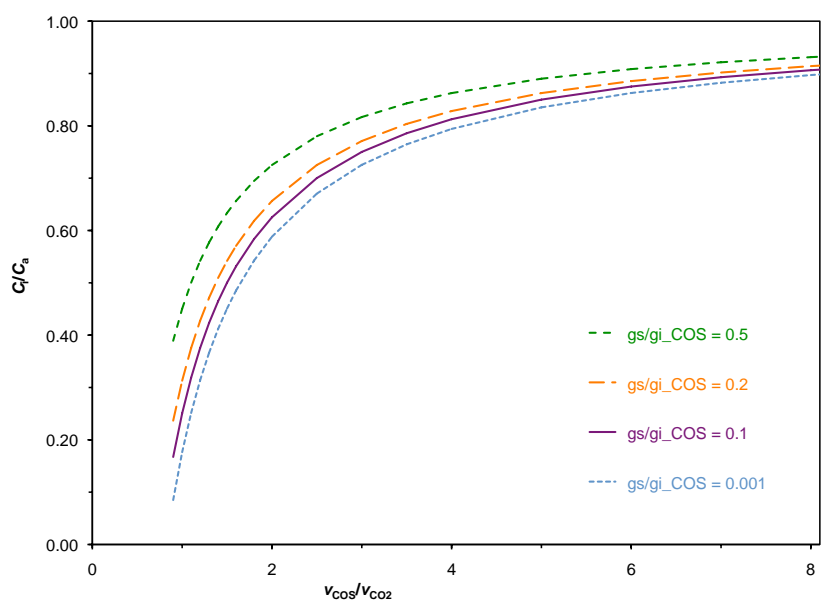

Fig. 3. Ratios of intercellular to ambient $\mathrm{CO}_{2}$ mole fraction, $C_{i} / C_{a}$, can be obtained from the normalized uptake ratios of $\mathrm{COS}$ to $\mathrm{CO}_{2}$, $v_{\mathrm{COS}} / v_{\mathrm{CO}_{2}}$, based on Eq. (9) and $R_{c-\mathrm{COS}}=1.2$. We assume that leaf internal conductance is much higher than stomatal conductance $\left(g_{s} \mathrm{COS} / g_{i \mathrm{COS}}=0.1\right.$ or 0.2$)$. Thus, neglecting this component (i.e. assigning a value of 0.001 ) does not make a large difference compared to including it. It is also possible that $g_{i} \mathrm{COS}$ is a more limiting part of the diffusional pathway (0.5), with a narrower range of $v_{\mathrm{COS}} / v_{\mathrm{CO}_{2}}$ corresponding to typical $C_{i} / C_{a}$ ratios.

3 correspond to $C_{i} / C_{a}$ from 0.63 to 0.75 , typical mean $C_{i} / C_{a}$ ratios of $\mathrm{C}_{3}$ plants under field conditions. In contrast, $v_{\mathrm{COS}} / v_{\mathrm{CO}_{2}}$ ratios below 1 or above 6 may indicate that processes other than photosynthetic uptake are contributing to the observed $\mathrm{COS}$ and/or $\mathrm{CO}_{2}$ fluxes (for example, $7.8 \pm 1.3$ for ecosystem scale uptake, recalculated from $\mathrm{Xu}$ et al., 2002). Neglecting internal resistance $\left(g_{s} \operatorname{COS} / g_{i \operatorname{COS}}=0.001\right)$ has little effect on the relationship between $v_{\mathrm{COS}} / v_{\mathrm{CO}_{2}}$ and $C_{i} / C_{a}$. On the other hand, if $g_{i \text { COS }}$ is a much stronger component of the diffusion pathway $\left(g_{s} \operatorname{COS} / g_{i} \operatorname{COS}=0.5\right)$, we would expect slightly lower $v_{\mathrm{COS}} / v_{\mathrm{CO}_{2}}$ of 1.5 to 2 for typical $C_{i} / C_{a}$ values.

Ratios of $v_{\mathrm{COS}} / v_{\mathrm{CO}_{2}}$ and corresponding $C_{i} / C_{a}$ for published data are listed in Table 2. Several values are above the typical $C_{i} / C_{a}$ range, probably because relative humidity and stomatal conductances are often higher in cuvettes compared to ambient conditions. Most $v_{\mathrm{COS}} / v_{\mathrm{CO}_{2}}$ ratios were calculated from $\mathrm{COS}$ and $\mathrm{CO}_{2}$ mole fractions in atmospheric air, but the conditions relevant for gas exchange calculations are those of the chamber air surrounding the leaves. Recalculating with chamber air mole fractions usually leads to higher $v_{\mathrm{COS}} / v_{\mathrm{CO}_{2}}$. For example, for the laboratory data on Fagus sylvatica presented in Fig. 1 (Sandoval-Soto et al., 2005), we obtained a mean $v_{\mathrm{COS}} / v_{\mathrm{CO}_{2}}$ of 2.4 based on air in the sample cuvette, substantially higher than the $v_{\mathrm{COS}} / v_{\mathrm{CO}_{2}}$ of 2.0 calculated from reference air. In addition, air supplied to chambers can have a very different composition than typical atmospheric air, particularly during laboratory experiments.
We assume that the enzyme CA is very efficient at converting the COS reaching the sites of reaction (Protoschill-Krebs et al., 1996), so that leaf COS uptake is primarily limited by diffusion. Biochemical studies are needed to resolve the extent to which CA activity may limit the overall rate. We implicitly include the CA reaction with the physical diffusion limitation in $g_{i}$ COs. As a consequence, even if there is an enzymatic preference of CA for $\mathrm{COS}$ over $\mathrm{CO}_{2}$, it is not expressed in $v_{\mathrm{COS}} / v_{\mathrm{CO}_{2}}$ values. Instead, the higher normalized uptake of COS compared to $\mathrm{CO}_{2}$ results from the higher reaction efficiency of $\mathrm{CA}$, relevant for COS, compared to $\mathrm{Ru}-$ bisco, relevant for $\mathrm{CO}_{2}$, associated with back diffusion of non-assimilated $\mathrm{CO}_{2}$ (see Montzka et al., 2007). This is expressed in the negligible internal concentration of COS compared to $\mathrm{CO}_{2}$ (Eqs. 2 and 4), and the coupling of $v_{\mathrm{COS}} / v_{\mathrm{CO}_{2}}$ to $C_{i} / C_{a}$ (Eq. 9).

Also listed in Table 2 are the $v_{\mathrm{COS}} / v_{\mathrm{CO}_{2}}$ values for a range of ecosystem types used to estimate global COS uptake by vegetation (Campbell et al., 2008). The global mean $v_{\mathrm{COS}} / v_{\mathrm{CO}_{2}}$ is 2.2 which corresponds to a $C_{i} / C_{a}$ of 0.66 , a typical ratio for $\mathrm{C}_{3}$ vegetation. Most ecosystem specific values are close to the global mean, except for one lower value of 0.44 for $C_{i} / C_{a}$ of boreal forests. The relationships for $v_{\mathrm{COS}} / v_{\mathrm{CO}_{2}}$ developed here should also hold for $\mathrm{C}_{4}$ plants, where CA is distributed throughout the mesophyll cells (Burnell and Hatch, 1988), but there is not enough data available for evaluation of Eq. (4).

Because of the direct coupling to stomatal conductance, measurements of COS fluxes could provide a valuable alternative to determine $C_{i} / C_{a}$ at high humidity, when water fluxes may be too small to be reliably determined. As an illustration, we calculated $C_{i} / C_{a}$ for Fagus sylvatica from stomatal conductance to $\operatorname{COS}\left(g_{s} \operatorname{COS}\right)$ and water vapour $\left(g_{s w}\right)$. Over three days, we found $C_{i} / C_{a}=0.67 \pm 0.07$ from $g_{s \operatorname{COS}}$, and $C_{i} / C_{a}=0.69 \pm 0.01$ from $g_{s w}$ (original data from Sandoval-Soto et al., 2005). The mean values are in good agreement, but the COS based estimate has larger uncertainties than the $g_{s w}$ based estimate.

\section{Estimating the normalized uptake ratio of $\operatorname{COS}$ to $\mathrm{CO}_{2}$ from carbon isotopes}

The relationships described above (Eq. 8) can also be used to obtain $v_{\mathrm{COS}} / v_{\mathrm{CO}_{2}}$ ratios from independent estimates of $C_{i} / C_{a}$. One possibility is to utilize the coupling of $C_{i} / C_{a}$ and photosynthetic ${ }^{13} \mathrm{C}$ discrimination to determine $v_{\mathrm{COS}} / v_{\mathrm{CO}_{2}}$ ratios. Indeed, the use of $\mathrm{COS}$ to investigate $\mathrm{CO}_{2}$ gas exchange is quite similar to the more traditional use of isotopic tracers in this context.

In its simplest form, ${ }^{13} \mathrm{C}$ discrimination $(\Delta, \%)$ during photosynthesis can be written as (Farquhar et al., 1982; Farquhar and Richards, 1984):

$\Delta=a+(\bar{b}-a) \frac{C_{i}}{C_{a}}$ 
Table 2. Normalized uptake ratios of $\mathrm{COS}$ to $\mathrm{CO}_{2}\left(v_{\mathrm{COS}} / v_{\mathrm{CO}_{2}}\right)$ and their corresponding $C_{i} / C_{a}$ ratios (based on Eq. (9), $\left.g_{s} \mathrm{COS} / g_{i} \mathrm{COS}=0.1\right)$ for published data (Sandoval-Soto et al., 2005), and ecosystem types used to estimate global COS uptake by vegetation (Campbell et al., 2008). Note that for published data from enclosure studies (except those recalculated from original data, indicated by $*$ ), $v_{\mathrm{COS}} / v_{\mathrm{CO}}$ was calculated from reference (or atmospheric) $\mathrm{COS}$ and $\mathrm{CO}_{2}$ mole fractions. As the mole fractions of the air surrounding the leaves (i.e. chamber air) should be used instead, their actual $v_{\mathrm{COS}} / v_{\mathrm{CO}_{2}}$ values could be 10 to $15 \%$ higher than listed in the table.

\begin{tabular}{|c|c|c|c|}
\hline Species & $v_{\mathrm{COS}} / v_{\mathrm{CO}_{2}}$ & $C_{i} / C_{a}$ & reference \\
\hline \multicolumn{4}{|l|}{ crops, lab enclosures } \\
\hline Brassica napus & 1.3 & 0.42 & Kesselmeier and Merk, 1993 \\
\hline \multirow[t]{2}{*}{ Pisum sativum } & 3.8 & 0.80 & \\
\hline & 3.1 & 0.76 & Hofmann, 1993 \\
\hline Triticum aestivum & 3.2 & 0.77 & \\
\hline \multicolumn{4}{|l|}{ trees, lab enclosures } \\
\hline Fagus sylvatica & $2.6^{*}$ & 0.71 & Sandoval-Soto et al., 2005 \\
\hline Quercus ilex & $2.4^{*}$ & 0.69 & \\
\hline Pinus sylvestris & $2.6^{*}$ & 0.71 & \\
\hline Picea abies & $1.4^{*}$ & 0.46 & \\
\hline \multicolumn{4}{|l|}{ trees, field enclosures } \\
\hline Picea abies & $8.7-10.3$ & $0.91-0.93$ & Huber, 1993 \\
\hline Quercus agrifolia & $1.8^{*}$ & 0.58 & Kuhn et al., 1999 \\
\hline Porterandia cladantha & 2.4 & 0.69 & Kesselmeier et al., 1993 \\
\hline Sacoglottis gabonensis & $1.7-5.5$ & $0.56-0.86$ & \\
\hline \multicolumn{4}{|l|}{ values used in global analysis } \\
\hline boreal forest, taiga & 1.35 & 0.44 & Campbell et al., 2008 \\
\hline flooded grasslands, savannas & 2.0 & 0.63 & \\
\hline temperate mixed forests & 2.35 & 0.68 & \\
\hline tropical and subtrop. forests & 2.65 & 0.72 & \\
\hline global mean & 2.2 & 0.66 & \\
\hline
\end{tabular}

where $a$ is the fractionation during $\mathrm{CO}_{2}$ diffusion through the stomata (4.4\%o, Craig, 1953), and $\bar{b}$ is the weighted fractionation during internal transfer of $\mathrm{CO}_{2}$ and fixation by Rubisco and PEPc. Using Eq. (10) to substitute $\Delta$ for $C_{i} / C_{a}$ in Eq. (8) yields:

$v_{\mathrm{COS}} / v_{\mathrm{CO}_{2}}=\frac{1}{R_{c-\mathrm{COS}}\left(1+g_{s \mathrm{COS}} / g_{i \mathrm{COS}}\right)} \frac{\bar{b}-a}{\bar{b}-\Delta}$

This relationship has the advantage that measurements of the $\delta^{13} \mathrm{C}$ of leaf samples, ecosystem exchange, or the results of atmospheric inversion studies, can be used to derive $v_{\mathrm{COS}} / v_{\mathrm{CO}_{2}}$ ratios independent of $\mathrm{CO}_{2}$ flux measurements. Here, we apply this approach to obtain $v_{\mathrm{COS}} / v_{\mathrm{CO}_{2}}$ for a global range of biomes (data from Table 2 in Lloyd and Farquhar (1994)). To be consistent with the original calculations, we derive $C_{i} / C_{a}$ from their equation (Eq. 4 of Lloyd and Farquhar (1994), $\bar{b}=27.5$, and including photorespiration) instead of Eq. (10). Most of the resulting $v_{\mathrm{COS}} / v_{\mathrm{CO}_{2}}$ ratios (Eq. 8) fall between 2 and 3 (Table 3, for the best guess $\left.g_{s} \operatorname{COS} / g_{i \operatorname{COS}}=0.1\right)$. The lowest ratios are derived for dry biomes such as semi-desert (1.7), whereas tropical forests tend to have the highest ratios, $>3$ (Table 3 ), reflecting the increase in stomatal conductance with decreasing evaporative demand.
We calculate a GPP weighted global mean $v_{\mathrm{COS}} / v_{\mathrm{CO}_{2}}$ ratio of $2.8 \pm 0.3$ (for $\mathrm{C}_{3}$ plants, Eqs. (8) and (11), possible variations in $g_{s} \mathrm{COS} / g_{i} \mathrm{COS}$ are included in the uncertainty estimate), larger or in the upper range of previous estimates (Sandoval-Soto et al., 2005; Montzka et al., 2007). With a global GPP estimate of $109.3 \mathrm{Pg} \mathrm{C} \mathrm{yr}^{-1}$ for 2001-2003 (Zhao et al., 2005), we estimate a global vegetation sink of COS in the order of $900 \pm 100 \mathrm{Gg} \mathrm{S} \mathrm{yr}^{-1}$. This is in the lower range of $730-1500 \mathrm{Gg} \mathrm{S} \mathrm{yr}^{-1}$ (Sandoval-Soto et al., 2005) and $1200 \pm 300 \mathrm{Gg} \mathrm{S} \mathrm{yr}^{-1}$ (Xu et al., 2002), but much higher than the estimate of $490 \mathrm{Gg} \mathrm{Syr}^{-1}$ (Suntharalingam et al., 2008).

\section{Conclusions}

We have developed a simple model of leaf COS uptake, analogous to the equations for leaf $\mathrm{CO}_{2}$ and water fluxes. We describe these equations as process-oriented (not processbased) because they all require estimates of stomatal conductance, for which we do not yet have a fully mechanistic understanding. Leaf COS uptake predicted from the new equation was in good agreement with data from field and laboratory chambers (Kuhn et al., 1999; Sandoval-Soto et al., 2005), although with large uncertainties. 
Table 3. Normalized uptake ratios of $\mathrm{COS}$ to $\mathrm{CO}_{2}\left(v_{\mathrm{COS}} / v_{\mathrm{CO}_{2}}\right)$ and $C_{i} / C_{a}$ obtained from estimates of ${ }^{13} \mathrm{C}$ discrimination $(\Delta)$ during photosynthesis (Lloyd and Farquhar, 1994), assuming that internal conductance is a negligible $\left(g_{s} \operatorname{COS} / g_{i \mathrm{COS}}=0.001\right)$, intermediate $(0.1$, 0.2 ), or large (0.5) limitation in the diffusional pathway of COS.

\begin{tabular}{|c|c|c|c|c|c|c|c|}
\hline Biome & $\begin{array}{c}\text { GPP } \\
\left(\text { Pmol yr }^{-1}\right)\end{array}$ & $\begin{array}{c}\Delta \\
(\%)\end{array}$ & $C_{i} / C_{a}$ & $(0.001)$ & $\begin{array}{c}v_{\mathrm{COS}} / v_{\mathrm{CO}_{2}} \\
(0.1)\end{array}$ & $(0.2)$ & $(0.5)$ \\
\hline Tropical rain forest & 3.46 & 18.4 & 0.76 & 3.40 & 3.09 & 2.83 & 2.27 \\
\hline Tropical seasonal forest & 0.77 & 18.9 & 0.78 & 3.71 & 3.38 & 3.10 & 2.48 \\
\hline Tropical savannah & 1.28 & 18.6 & 0.77 & 3.51 & 3.20 & 2.93 & 2.35 \\
\hline Evergreen warm mixed forest & 0.14 & 19.0 & 0.77 & 3.63 & 3.31 & 3.03 & 2.42 \\
\hline Cool/cold deciduous forest & 0.28 & 19.6 & 0.79 & 3.96 & 3.60 & 3.30 & 2.64 \\
\hline Cool/cold mixed forest & 0.20 & 18.3 & 0.73 & 3.08 & 2.80 & 2.57 & 2.05 \\
\hline Cool/cold conifer forest & 0.47 & 15.4 & 0.60 & 2.08 & 1.89 & 1.74 & 1.39 \\
\hline Taiga & 0.12 & 15.6 & 0.61 & 2.14 & 1.94 & 1.78 & 1.43 \\
\hline Xerophytic woods and scrub & 0.07 & 12.9 & 0.52 & 1.70 & 1.55 & 1.42 & 1.14 \\
\hline Grasslands and shrub & 0.51 & 15.5 & 0.62 & 2.19 & 2.00 & 1.83 & 1.46 \\
\hline Grasslands & 0.82 & 17.4 & 0.70 & 2.77 & 2.53 & 2.31 & 1.85 \\
\hline Dryland agronomy & 0.80 & 17.0 & 0.69 & 2.62 & 2.39 & 2.19 & 1.75 \\
\hline Irrigated agronomy/ horticulture & 0.07 & 16.4 & 0.67 & 2.48 & 2.26 & 2.07 & 1.66 \\
\hline Dryland tropical horticulture & 0.05 & 15.0 & 0.61 & 2.12 & 1.93 & 1.77 & 1.41 \\
\hline Tundra & 0.25 & 16.1 & 0.63 & 2.22 & 2.02 & 1.86 & 1.48 \\
\hline Semi-desert & 0.06 & 14.2 & 0.57 & 1.92 & 1.75 & 1.60 & 1.28 \\
\hline Paddy rice & 0.33 & 18.0 & 0.74 & 3.16 & 2.87 & 2.63 & 2.11 \\
\hline Mangroves & 0.05 & 15.5 & 0.64 & 2.26 & 2.06 & 1.89 & 1.51 \\
\hline GPP weighted mean & & 17.8 & 0.73 & 3.11 & 2.83 & 2.60 & 2.08 \\
\hline
\end{tabular}

As a consequence of the close coupling of leaf $\operatorname{COS}$ and $\mathrm{CO}_{2}$ uptake, the normalized uptake ratio of $\mathrm{COS}$ and $\mathrm{CO}_{2}$ can be used to provide estimates of $C_{i} / C_{a}$, the ratio of intercellular to atmospheric $\mathrm{CO}_{2}$, an important plant gas exchange parameter that cannot be measured directly. In addition, $\mathrm{COS}$ and ${ }^{13} \mathrm{C}$ discrimination can be combined to obtain independent estimates of photosynthesis (GPP). The new process-oriented description provides a framework for understanding $\mathrm{COS}$ fluxes that should improve the usefulness of atmospheric $\mathrm{COS}$ and $\mathrm{CO}_{2}$ measurements to obtain estimates of gross photosynthesis at regional to global scales.

To develop COS into a reliable proxy for $C_{i} / C_{a}$ and GPP, we now need to reduce the experimental uncertainties, characterize concurrent terrestrial fluxes such as soil COS uptake, and evaluate the assumptions and parameters of the new COS model (Eq. 4) under a wide range of environmental conditions. With better analytical precision, COS could also become a valuable addition to measurements at the ecosystem scale, particularly when water measurements are difficult or impossible due to high humidity, for example in tropical ecosystems. Thus, COS has the potential to provide new constraints on stomatal and canopy conductance, a fundamental - and difficult to measure - plant process that regulates the exchange of carbon, water and energy of the terrestrial biosphere.

\section{Appendix A}

\section{Equations including internal conductance}

The following provides alternative versions of the above equations, with internal conductance included directly. The total leaf conductances to $\mathrm{CO}_{2}$ and $\mathrm{COS}\left(g_{t c}, g_{t \mathrm{COS}}\right)$ combine stomatal conductance $\left(g_{s c}, g_{s \mathrm{COS}}\right)$ and internal conductance to the reaction sites $\left(g_{i c}, g_{i \mathrm{COS}}\right)$ :

$g_{t}=\left(\frac{1}{g_{s}}+\frac{1}{g_{i}}\right)^{-1}$

Leaf uptake of $\mathrm{CO}_{2}$ and $\mathrm{COS}\left(F_{c}, F_{\mathrm{COS}}\right)$ can be written as:

$$
\begin{aligned}
& F_{c}= g_{t c}\left(C_{a, c}-C_{c, c}\right)=g_{s c}\left(C_{a, c}-C_{i, c}\right) \\
&= g_{i c}\left(C_{i, c}-C_{c, c}\right) \\
& F_{\mathrm{COS}}=g_{t} \operatorname{COS}\left(C_{a \mathrm{COS}}-C_{m} \mathrm{COS}\right)=g_{s} \mathrm{COS} \\
& \quad\left(C_{a \operatorname{COS}}-C_{i \mathrm{COS}}\right)=g_{i \operatorname{COS}}\left(C_{i \operatorname{COS}}-C_{m \mathrm{COS}}\right)
\end{aligned}
$$

to illustrate the parallel diffusion pathways of $\mathrm{CO}_{2}$ and $\mathrm{COS}$ from ambient air (mole fractions $C_{a, c}, C_{a \mathrm{COS}}$ ) into the intercellular spaces $\left(C_{i, c}, C_{i \mathrm{COS}}\right)$. The internal component of the COS pathway $\left(g_{i} \mathrm{COS}\right)$ indirectly includes the reaction with carbonic anhydrase (CA). In contrast to the $\mathrm{CO}_{2}$ mole fraction in the chloroplasts $\left(C_{c, c}\right)$, we assume $C_{m} \operatorname{COS} \ll C_{a} \mathrm{COS}$ (Protoschill-Krebs et al., 1996; Sandoval-Soto et al., 2005; 
Notni et al., 2007), and rewrite Eq. (2) as:

$$
\begin{aligned}
F_{\mathrm{COS}} & =g_{t \operatorname{COS}} C_{a \mathrm{COS}}=g_{s} \operatorname{COS}\left(C_{a \mathrm{COS}}-C_{i \mathrm{COS}}\right) \\
& =g_{i \operatorname{COS}} C_{i \mathrm{COS}}
\end{aligned}
$$

Using Eqs. (A2) and (A4), the normalized uptake rates of $\mathrm{CO}_{2}$ and $\mathrm{COS}$ are:

$v_{\mathrm{CO}_{2}}=\frac{F_{c}}{C_{a, c}}=g_{t c}\left(1-\frac{C_{c, c}}{C_{a, c}}\right)=g_{s c}\left(1-\frac{C_{i, c}}{C_{a, c}}\right)$

$v_{\mathrm{COS}}=\frac{F_{\mathrm{COS}}}{C_{a \mathrm{COS}}}=g_{t \mathrm{COS}}=g_{s \mathrm{COS}}\left(1-\frac{C_{i \mathrm{COS}}}{C_{a \mathrm{COS}}}\right)$

and the normalized uptake ratio of $\operatorname{COS}$ to $\mathrm{CO}_{2}$ can be written as:

$$
\begin{gathered}
v_{\mathrm{COS}} / v_{\mathrm{CO}_{2}}=\frac{g_{t} \mathrm{COS}}{g_{t c}}\left(1-\frac{C_{c, c}}{C_{a, c}}\right)^{-1}=\frac{1}{R_{c-\operatorname{COS}}} \frac{1+\frac{g_{s c}}{g_{i c}}}{1+\frac{g_{s c O S}}{g_{i C O S}}}\left(1-\frac{C_{c, c}}{C_{a, c}}\right)^{-1} \\
=\frac{g_{t} \mathrm{COS}}{g_{s c}}\left(1-\frac{C_{i, c}}{C_{a, c}}\right)^{-1}=\frac{1}{R_{c-\operatorname{COS}}} \frac{1}{1+\frac{g_{s c O S}}{g_{i \mathrm{COS}}}}\left(1-\frac{C_{i, c}}{C_{a, c}}\right)^{-1}
\end{gathered}
$$

where the stomatal conductances are related by a constant factor $\left(R_{c-\mathrm{COS}}=g_{s c} / g_{s \mathrm{COS}} \approx 1.2\right)$. As an example, using an internal conductance of $0.2 \mathrm{~mol} \mathrm{~m}^{-2} \mathrm{~s}^{-1}$ for both $\mathrm{CO}_{2}$ and $\mathrm{COS}$, we would obtain for an average $\mathrm{CO}_{2}$ stomatal conductance of $g_{s c}=0.1 \mathrm{~mol} \mathrm{~m}^{-2} \mathrm{~s}^{-1}$ from Eq. (A7):

$v_{\mathrm{COS}} / v_{\mathrm{CO}_{2}} \approx 0.9\left(1-\frac{C_{c, c}}{C_{a, c}}\right)^{-1} \approx 0.6\left(1-\frac{C_{i, c}}{C_{a, c}}\right)^{-1}$

Accounting for internal conductance, ${ }^{13} \mathrm{C}$ discrimination during photosynthesis can be written as (Farquhar et al., 1982):

$\Delta=a \frac{C_{a, c}-C_{i, c}}{C_{a, c}}+a_{m} \frac{C_{i, c}-C_{c, c}}{C_{a, c}}+b \frac{C_{c, c}}{C_{a, c}}$

where $a$ and $a_{m}$ are the fractionations during stomatal diffusion and internal transfer of $\mathrm{CO}_{2}$, and $b$ is the weighted fractionation during fixation by Rubisco and PEPc.

With the approximation $C_{i, c}-C_{c, c}=0.1 C_{a, c}$ (Lloyd and Farquhar, 1994), this yields:

$\Delta \approx 0.9 a+0.1 a_{m}+(b-a) \frac{C_{c, c}}{C_{a, c}}$

and can be combined with Eq. (7) to:

$v_{\mathrm{COS}} / v_{\mathrm{CO}_{2}} \approx \frac{g_{t \mathrm{COS}}}{g_{t c}} \frac{b-a}{b-\Delta-0.1\left(a-a_{m}\right)}$

Additional processes such as boundary layer conductance and photorespiration can be included similarly in the above equations.

Acknowledgements. We are grateful to Parv Suntharalingam, Graham Farquhar, and the two referees for discussions, helpful comments and suggestions. The research leading to these results has received funding from the European Research Council under the European Community's Seventh Framework Programme (FP7/2007-2013)/ERC Grant Agreement no. 202835 “COSIRIS”.

Edited by: C. Spirig

\section{References}

Andreae, M. O. and Crutzen, P. J.: Atmospheric aerosols - Biogeochemical sources and role in atmospheric chemistry, Science, 276, 1052-1058, 1997.

Bird, R. B., Stewart, W. E., and Lightfoot, E. N.: Transport Phenomena (Revised Second Edition), John Wiley and Sons, New York, 2007.

Burnell J. N. and Hatch, M. D.: Low bundle sheath carbonic anhydrase is apparently essential for effective $\mathrm{C}_{4}$ pathway operation, Plant Physiol., 86, 1252-1256, 1988.

Campbell, J. E., Carmichael, G. R., Chai, T., Mena-Carrasco, M., Tang, Y., Blake, D. R., Blake, N. J., Vay, S. A., Collatz, G. J., Baker, I., Berry, J. A., Montzka, S. A., Sweeney, C., Schnoor, J. L., and Stanier, C. O.: Photosynthetic control of atmospheric carbonyl sulfide during the growing season, Science, 322, 1085 1088, 2008.

Chin, M. and Davis, D. D.: Global sources and sinks of OCS and $\mathrm{CS}_{2}$ and their distribution, Global Biogeochem. Cy., 7, 321-337, 1993.

Cowan, I. R.: Stomatal behavior and environment. Adv. Bot. Res., 4, 117-228, 1977.

Craig, H.: The geochemistry of the stable carbon isotopes, Geochim. Cosmochim. Acta, 3, 53-92, 1953.

Crutzen, P. J.: The possible importance of CSO for the sulfate layer of the stratosphere, Geophys. Res. Lett., 3, 73-76, 1976.

Farquhar, G. D. and Richards, R. A.: Isotopic composition of plant carbon correlates with water use efficiency of wheat genotypes, Austr. J. Plant Physiol., 11, 539-552, 1984.

Farquhar, G. D., OLeary, M. H., and Berry, J. A.: On the relationship between carbon isotope discrimination and the intercellular carbon dioxide concentration in leaves, Austr. J. Plant Physiol., 9, 121-137, 1982.

Hoffmann, U.: Der Austausch von reduzierten SchwefelVerbindungen zwischen Vegetation und Atmosphäre: Interpretation von Versuchen im Freiland in Verbindung mit mechanistischen Experimenten im Labor, Ph.D. thesis, Univ. Mainz, Germany, 1993.

Huber, B.: Austausch flüchtiger Schwefelverbindungen in landund forstwirschaftlichen Ökosystemen, Ph.D. thesis, Techn. Univ. München, Germany, 1993.

Kesselmeier, J. and Merk, L.: Exchange of carbonyl sulfide (COS) between agricultural plants and the atmosphere: Studies on the deposition of COS to peas, corn and rapeseed, Biogeochemistry, 23, 47-59, 1993.

Kesselmeier, J., Meixner, F. X., Hofmann, U., Ajavon, A., Leimbach, S., and Andreae, M. O.: Reduced sulfur compound exchange between the atmosphere and tropical tree species in southern Cameroon, Biogeochemistry, 23, 23-45, 1993.

Kesselmeier, J., Teusch, N., and Kuhn, U.: Controlling variables for the uptake of atmospheric carbonyl sulfide (COS) by soil, J. Geophys. Res.-Atmos., 104(D9), 11577-11584, 1999.

Kettle, A. J., Kuhn, U., von Hobe, M., Kesselmeier, J., and Andreae, M. O.: The global budget of atmospheric carbonyl sulfide: Temporal and spatial modulation of the dominant sources and sinks, J. Geophys. Res., 107(D22), 4658, doi:10.1029/2002JD002187, 2002.

Kuhn, U., Wolf, A., Ammann, C., Meixner, F. X., Andreae, M. O., and Kesselmeier, J.: Carbonyl sulfide exchange on an ecosystem scale: Soil represents a dominant sink for atmospheric COS, 
Atmos. Environ., 33, 995-1008, 1999.

Lide, D. R. (ed.): CRC Handbook of Chemistry and Physics online (89th ed.), CRC Press, USA, 2008.

Lloyd, J. and Farquhar, G. D.: ${ }^{13} \mathrm{C}$ discrimination during $\mathrm{CO}_{2}$ assimilation by the terrestrial biosphere, Oecologia, 99, 201-215, 1994.

Massman, W. J.: A review of the molecular diffusivities of $\mathrm{H}_{2} \mathrm{O}$, $\mathrm{CO}_{2}, \mathrm{CH}_{4}, \mathrm{CO}, \mathrm{O}_{3}, \mathrm{SO}_{2}, \mathrm{NH}_{3}, \mathrm{~N}_{2} \mathrm{O}, \mathrm{NO}$, and $\mathrm{NO}_{2}$ in air, $\mathrm{O}_{2}$ and $\mathrm{N}_{2}$ near STP, Atmos. Environm., 32, 1111-1127, 1998.

Montzka, S. A., Calvert P., Hall B. D., Elkins J. W., Conway T. J., Tans P. P., and Sweeney C.: On the global distribution, seasonality, and budget of atmospheric carbonyl sulfide (COS) and some similarities to $\mathrm{CO}_{2}$, J. Geophys. Res., 112, D09302, doi:10.1029/2006JD007665, 2007.

Notni, J., Schenk, S., Protoschill-Krebs, G., Kesselmeier, J., and Anders, E.: The missing link in COS metabolism: A model study on the reactivation of carbonic anhydrase from its hydrosulfide analogue, ChemBioChem, 8, 530-536, 2007.

Penman, H. L. and Schofield, R. K.: Some physical aspects of assimilation and transpiration, Symp. Soc. Exp. Biol., 5, 115-129, 1951.

Protoschill-Krebs, G., Wilhelm, C., and Kesselmeier, J.: Consumption of carbonyl sulde by carbonic anhydrase (CA) isolated from Pisum sativum, Atmos. Environ., 30, 3151-3156, 1996.

Sandoval-Soto, L., Stanimirov, M., von Hobe, M., Schmitt, V., Valdes, J., Wild, A., and Kesselmeier, J.: Global uptake of carbonyl sulfide (COS) by terrestrial vegetation: Estimates corrected by deposition velocities normalized to the uptake of carbon dioxide $\left(\mathrm{CO}_{2}\right)$, Biogeosciences, 2, 125-132, 2005 ,

http://www.biogeosciences.net/2/125/2005/.
Suntharalingam, P., Kettle, A. J., Montzka, S. M., and Jacob, D. J.: Global 3-D model analysis of the seasonal cycle of atmospheric carbonyl sulfide: Implications for terrestrial vegetation uptake, Geophys. Res. Lett., 35, L19801, doi:10.1029/2008GL034332, 2008.

Van Diest, H. and Kesselmeier, J.: Soil atmosphere exchange of carbonyl sulfide (COS) regulated by diffusivity depending on waterfilled pore space, Biogeosciences, 5, 475-483, 2008, http://www.biogeosciences.net/5/475/2008/.

von Hobe, M., Kenntner, T., Helleis, F. H., Sandoval-Soto, L., and Andreae, M. O.: Cryogenic trapping of carbonyl sulfide without using expendable cryogens, Anal. Chem., 72, 5513-5515, 2000.

Watts, S. F.: The mass budgets of carbonyl sulfide, dimethyl sulfide, carbon disulfide and hydrogen sulfide, Atmos. Environ., 34, 761779, 2000.

$\mathrm{Xu}, \mathrm{X}$. , Bingemer, H. G., and Schmidt, U.: The flux of carbonyl sulfide and carbon disulfide between the atmosphere and a spruce forest, Atmos. Chem. Phys., 2, 171-181, 2002, http://www.atmos-chem-phys.net/2/171/2002/.

Zhao, M., Heinsch, F. A., Nemani, R. R., Running, S. W.: Improvements of the MODIS terrestrial gross and net primary production global data set, Remote Sens. Environ., 95, 164-176, 2005. 